\title{
Early-Arbuscular Mycorrhizal Fungi-Application Improved Physiological Performances of Sugarcane Seedling and Further Growth in the Dry Land
}

\author{
Wawan Sulistiono ${ }^{1}$, Taryono ${ }^{2}$, Prapto Yudono ${ }^{3} \&$ Irham $^{4}$ \\ ${ }^{1}$ Assessment Institute for Agricultural Technology of North Maluku, Sofifi, Indonesia \\ ${ }^{2}$ Departemant of Plant Breeding Science, Faculty of Agriculture, Universitas Gadjah Mada, Yogyakarta, \\ Indonesia \\ ${ }^{3}$ Departemant of Agronomy, Faculty of Agriculture, Universitas Gadjah Mada, Yogyakarta, Indonesia \\ ${ }^{4}$ Environmental Science, Faculty of Agriculture, Universitas Gadjah Mada, Yogyakarta, Indonesia \\ Correspondence: Wawan Sulistiono, Assessment Institute for Agricultural Technology of North Maluku, Sofifi, \\ Indonesia. Tel: 62-821-9677-3678. E-mail: tionojanah@gmail.com
}

\author{
Received: December 27, 2016 \\ Accepted: February 4, 2017 \\ Online Published: March 15, 2017 \\ doi:10.5539/jas.v9n4p95 \\ URL: https://doi.org/10.5539/jas.v9n4p95
}

The research if financed by LPPM Universitas Gadjah Mada Yogyakarta Indonesia with award number LPPM-UGM/396/LIT/2014.

\begin{abstract}
The Indonesian sugarcane production in the dryland was not optimal due to physiological stress. The research to improve their physiological characteristics by arbuscular mycorrhizal application was conducted at inceptisol soil from April 2014 to February 2015, using factorial completely randomized design. The first factor was clones PS864, Kidangkencana, PS881, Bululawang, and VMC, whereas the second factor was timing of arbuscular mycorrhizal inoculum applications i.e.: in the field, nursery, and control. The results show that the mycorrhizal application in the nursery significantly increased the infection percentage $(41.3 \%)$ at the age of 1 week after transplanting to the field. There are differences in physiological and growth performance of clones by the effect of timing of mycorrhizal application. Bululawang with mycorrhizal application in the nursery stage tended to have better physiological performance such as chlorophylls a, b, and total chlorophyll, photosynthesis rate, intercellular $\mathrm{CO}_{2}$ concentration, leaf area, as well as the weight of stem biomass. Mycorrhizal application in the nursery stage showed the highest increase of net assimilation rate on the PS864 and, BL clones, and the highest crop growth rate on the PS864, KK and BL clones. The mycorrizal inoculum application in the nursery increased the biomass weight of stem (11-61.1\%). Infection percentage of mycorrhiza was positively correlated with the biomass weight with $\mathrm{r}^{2}$ values of 0.54 .
\end{abstract}

Keywords: sugarcane, mycorrhiza, physiological performances, transplanting, dryland

\section{Introduction}

During the last 15 years, Indonesian sugarcane area has been shifting from fertile to marginal land particularly dry land. The percentage of dry land area reaches $60 \%$ of the total sugarcane area at national level (Central Bureau of Statistics, 2013). The constraint of growing sugarcane in dryland is its high dependence on seasons which provide sufficient rainfall and humidity of the soil (Gana, 2011; Hongwei et al., 2000).

With these limitations, sugarcane plants underwent physiological changes such as a decrease in chlorophyll content, stomatal conductivity, photosynthetic rate, and transpiration rate, and eventually a decrease in plant biomass production (Graca et al., 2010; Medeiros et al., 2013; Zhao et al., 2013). Soil water deficit can decrease both stomatal conductance and leaf water potential (Boyle et al., 2015). In this condition water deficit can reduce the net photosynthesis by causing stomatal closure which reduces the $\mathrm{CO}_{2}$ diffusion inside the leaf, and in turn the net photosynthesis (Pasternak \& Wilson, 1974; Lawlor \& Cornic, 2002). Water stress condition reduced cane yield (tons of cane per hectare) and total dry matter by $17-52 \%$ and $20-56 \%$ respectively. Basnayake et al. (2012) and Zhao et al. (2010) reported that the drought during the grand growing phase caused a decrease by $53 \%$ in 
millable cane on sandy soils. Therefore, raising the productivity of dry land for sugarcane becomes strategic to increase national production by adopting new technology.

It is well known that traditionally sugarcane was cultivated by using whole stems directly planted in the field. The disadvantage of this technique was it required plenty of materials, i.e. 6-8 tons of cuttings/ha (Omoto et al., 2007) but produced few productive shoots, in some cases only 2 stems per clump (Natarajan, 2011).

Efforts were made to improve sugarcane productivity in the dryland by adopting the transplanting technique of bud chip seedling (Goud, 2011; Kumar \& Suresh, 2011) and inoculation of arbuscular mycorrhiza (Surendran \& Vani, 2013). The system of seedling transplantation shortens the age of plants in the field by one month compared with that of a conventional system so that late harvest can be avoided (Jain et al., 2010). The role of mycorrhiza in increasing the sugarcane yield is by increasing the number of shoots per clump, stem height and stem diameter, and improving the soil $\mathrm{pH}$ (pH 6.4-6.9) (Fundora et al., 2008). Additionally, the role of mycorrhiza is to increase the existence of quality soil microbes, thus increasing the colonization (Douds et al., 2014).

In the drylands where soil humidity and nutrient element are limited, plants with a better rooting system are needed to effectively absorb nutrients. The absorption of $\mathrm{P}$ element in the roots that happens in a symbiotic form with mycorrhiza is 3-5 times higher than that of without mycorrhiza (S. E. Smith \& F. A. Smith, 2012). Greater absorption rate by the rooting volume and the protein system of the root cell leads to greater availability and absorption of P (Schachtman et al., 1998). The mycorrhizal induced small secreted protein 7 (MiSSP7) found in the roots is known to be a signal of protein symbiosis in the host's roots (Plett et al., 2011).

The bud chip seedling transplantation with mycorrhiza is expected to improve sugarcane growth in drylands. However, the effect of the timing of AMF inoculum application on the physiology of sugarcane is not yet known. In several studies, the application of mycorrhiza has been done concurrently with basic fertilization. Rani et al. (2013) showed that the application of mycorrhiza in combination with organic fertilizers produced higher sugarcane's sucrose and sugar. Serna-Cock et al. (2011) reported that the application of microorganism (Azospirillum sp) as a basic fertilizer on sugarcane increased stem diameter (22.3\%), root length $(42.42 \%)$, and number of roots $(33.3 \%)$ at the age of 45 days after application. Therefore, a study on the effect of arbuscular mycorrhiza inoculum application times, which means in the nursery and the field on the physiology of sugarcane plants with bud chip seedling transplantation in dryland, is deemed necessary.

\section{Materials and Methods}

\subsection{Plant Culture and Treatments}

The research was carried out in sandy soil of dry land of Harjobinangun village of Pakem, district of Sleman, Yogyakarta Special Province, Indonesia, $600 \mathrm{~m}$ above sea level from April 2014 to February 2015. The geographical positions of the research site were $77.66708^{\circ} \mathrm{SL}$ and $110.42011^{\circ} \mathrm{EL}$, whereas the highest and the lowest temperatures were $32{ }^{\circ} \mathrm{C}$ and $18{ }^{\circ} \mathrm{C}$ respectively.

The experiment was conducted at a farmer's field using Factorial Completely Randomized Design. Factor I of sugarcane clones consisted of PS864, Kidang kencana (KK), PS881, Bululawang (BL), and VMC. Factor II of AMF inoculum application times consisted of application in the nursery (MN), application in the field (MF), control (without application of mycorrhiza) (NM). The number of propagules used for each treatment combination was 50 single buds. In the application of mycorrhiza inoculum in the nursery, the seedlings were inoculated with AMF inoculum shortly after the bud chips were placed into polybags in the nursery. During the mycorrhizal application in the field, the seedlings were inoculated with AMF inoculum soon as it was moved into a larger polybag $(45 \times 45 \mathrm{~cm})$ in the field. The AMF inoculum dose was 1 gram of zeolite granular every polybag.

The experiment was conducted by raising seedlings of bud chips in $8 \times 12 \mathrm{~cm}$ polybags consisting of five sugarcane clones with 50 polybags per unit of treatment which was replicated 4 times. The 40 day-old-seedlings in the seedbeds were transplanted to the field using soil as media in large polybags $(45 \times 45 \mathrm{~cm})$. The plants were maintained by fertilizing, weeding, and earthing up. The fertilizers used were ZA for N, SP-36 for P, and $\mathrm{KCl}$ for $\mathrm{K}$ sources. The $\mathrm{N}$ dose was $2 \mathrm{~g} / \mathrm{plant}$ given during transplantation as much as 0.67 gram and $1.3 \mathrm{~g}$ at the age of 60 days. $\mathrm{P}$ and $\mathrm{K}$ doses of $1 \mathrm{~g}$ per plant were given during seedling transplantation. Weeding was done at the age of 30 days after transplantation.

The arbuscular mycorrhizal fungi (AMF) inoculum was propagated in zeolite granular media. The AMF was obtained by collecting the fungi from various regions on Java Island of Indonesia. The number of mycorrhizal spores applied was 358 spores per 100 gram media. Some genera of AMF obtained from isolation were Glomus 
sp., Funneliformis sp., Acaulospora sp., Gigaspora sp., and Scutellospora sp. The soil type of research was inceptisol with the soil physicochemical properties included $\mathrm{pH}$ of $\mathrm{H}_{2} \mathrm{O} 6.80, \mathrm{C}$ organic $1.74 \%$, cation exchange capacity $6.69 \mathrm{cmol}(+) / \mathrm{kg}$, total $\mathrm{N} 0.10 \%$, available of P $4.25 \mathrm{ppm}$, texture (sand, clay, and dust by $65.22,12.16$, and $22.62 \%$ respectively).

\subsection{Measurements}

The parameters observed were percentage of infection, photosynthetic rate (Pn), intercellular $\mathrm{CO}_{2}$ concentration (Ci), chlorophyll content, leaf area, net assimiliaton rate (NAR), crop growth rate (CGR), and biomass weight. The infection percentage was measured by using modified Clearing and Staining (Kormonik \& McGrow, 1982). Sixty root cuttings $(1 \mathrm{~cm})$ per treatment unit were randomly chosen from the sample plants. Observation was done from the first to the eleventh week after transplantation.

The photosynthetic components such as $\mathrm{Pn}$ and $\mathrm{Ci}$ were measured by using portable photosynthetic analyzer of Licor 6400 (LI-Cor. Inc. Lincoln, Nebraska, USA). Observation was done at the age of 5 weeks after transplantation with three plant samples per treatment unit. Measurement of chlorophylls a, b, and total was done by using Winterman and Demonts method (1964) with the observation time at the age of 5 weeks after transplantation.

The leaf area was measured at the age of 5 weeks after transplantation from the sample plants using leaf area meter in the plant production laboratory of the Faculty of Agriculture, Universitas Gadjah Mada (UGM). The leaves were separated from the leaf-stalk, and cut $(15 \mathrm{~cm})$. Net asimilation rate (NAR) and Crop growth rate (CGR) observation were done using Blacman formula (1919). The weight of stem biomass was measured at the age of 7 months.

\subsection{Data Analysis}

The data were analyzed according to the intervals of observation with analysis of variance (ANOVA) of factorial CRD using SAS 9 program for Windows. If there was an interaction between factors, a comparison of the interaction effects was made. Otherwise, means of treatment effect were compared based on Duncan's multiple range test at $\mathrm{p}<0.05$.

\section{Results}

\subsection{Percentage of Mycorrhizal Infection}

The infection of arbuscular mycorrhiza on the sugarcane rooting system of bud chips in the field was significantly affected by the timing of mycorrhizal inoculum application. There was no difference in infection percentage of different clones and there was no interaction between AMF inoculum application times and clones on the infection percentage (Table 1).

Table 1. Two-way ANOVA of mycorrhiza root infection 1-11 weeks after transplanting

\begin{tabular}{llllllll}
\hline \multirow{2}{*}{ Source } & \multirow{2}{*}{ df } & \multicolumn{5}{c}{ Mycorrhizal infection at the age of weeks after transplanting } \\
\cline { 3 - 7 } & & 1 & 3 & 5 & 7 & 9 & 11 \\
\hline Clone & 4 & 0.4507 & 0.3907 & 0.1497 & 0.7137 & 0.2576 & 0.1171 \\
Time of mycorrhiza application & 2 & $<.0001$ & $<.0001$ & $<.0001$ & $<.0001$ & $<.0001$ & $<.0001$ \\
Interaction & 8 & 0.2656 & 0.1770 & 0.0957 & 0.7813 & 0.2931 & 0.4810 \\
CV & & 30.57 & 28.55 & 11.57 & 11.69 & 7.72 & 8.11 \\
\hline
\end{tabular}

Note. Number in the table represent the probability values; Analysis was performed on 40 roots for each root order per replicate.

The mycorrhizal application in the nursery accelerated and increased the colonization percentage significantly at the beginning of seedling transplantation in the field (Table 2 and Figure 1). Earlier inoculation especially at nursery provided an opportunity for the mycorrhizal fungi to colonize the roots soon. 
Table 2. The effect of different AMF inoculum applications on the infection percentage of mycorrhiza

\begin{tabular}{lllllllll}
\hline \multirow{2}{*}{ AMF application } & \multicolumn{7}{l}{ Infection percentage of mycorrhiza at the age of weeks after transplanting } \\
\cline { 2 - 10 } & 1 & 2 & 3 & 5 & 6 & 7 & 9 & 11 \\
\hline In the field & $9.67 \mathrm{~b}$ & $30.00 \mathrm{~b}$ & $41.67 \mathrm{~b}$ & $77.67 \mathrm{~b}$ & $87.33 \mathrm{~b}$ & $91.67 \mathrm{a}$ & $95.33 \mathrm{a}$ & $96.00 \mathrm{a}$ \\
In the nursery & $41.33 \mathrm{a}$ & $55.33 \mathrm{a}$ & $71.00 \mathrm{a}$ & $83.67 \mathrm{a}$ & $94.00 \mathrm{a}$ & $97.33 \mathrm{a}$ & $99.33 \mathrm{a}$ & $99.00 \mathrm{a}$ \\
Control & $5.66 \mathrm{c}$ & $16.34 \mathrm{c}$ & $28.33 \mathrm{c}$ & $40.67 \mathrm{c}$ & $47.66 \mathrm{c}$ & $52.33 \mathrm{~b}$ & $53.99 \mathrm{~b}$ & $55.33 \mathrm{~b}$ \\
\hline
\end{tabular}

Note. The numbers followed by same letters in the same column are not significantly different based on Duncan's multiple range test at $\mathrm{p}<0.05$.

In the nursery mycorrhizal application, acceleration of the percentage of mycorrhiza infection reaches $41.3 \%$ at the age of 1 week after transplantation. In addition, this treatment also significantly increased the percentage of mycorrhiza infection in early transplanting (83.67\%) (Table 2 and Figure 1).

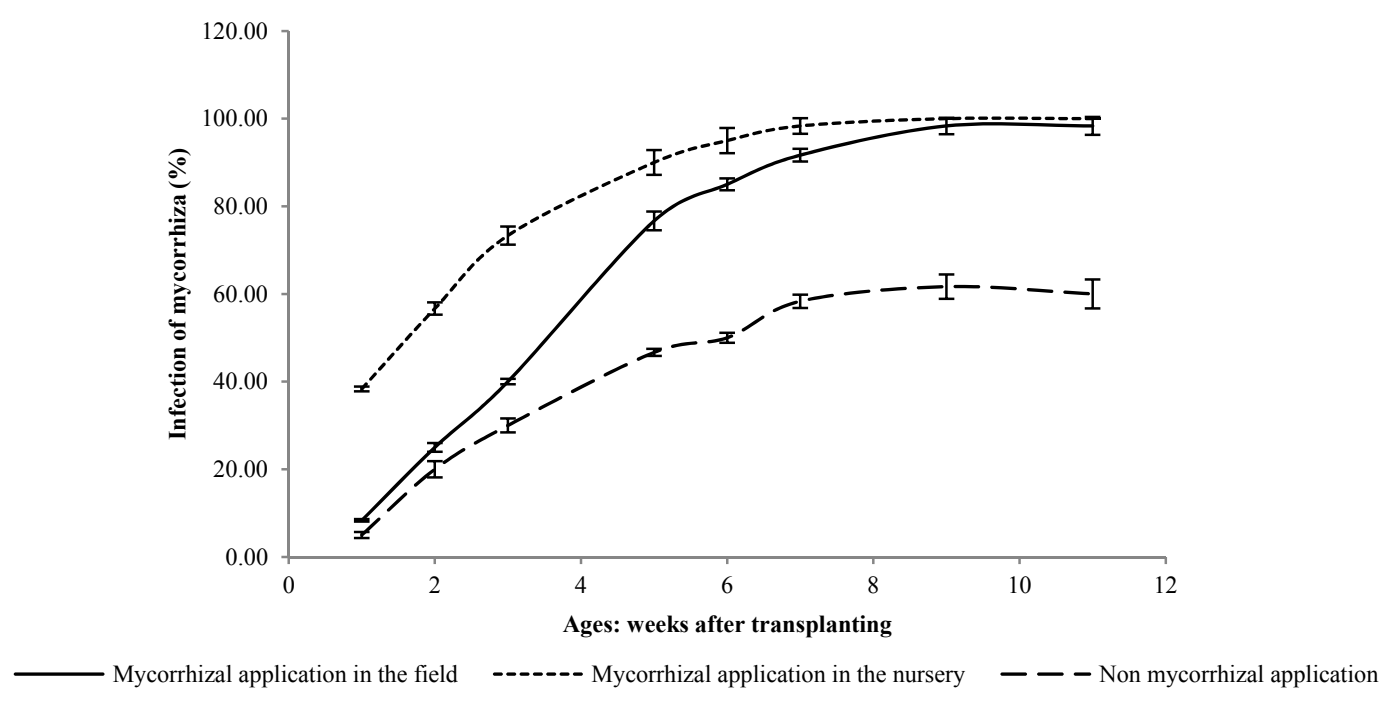

Figure 1. The percentage of mycorrhizal infection on BL clones under different AMF inoculum application timings

Note. The vertical line of the graph shows the individual distribution of treatment data $\mathrm{p} \leq 0.05$.

Mycorrhizal infection on the roots of sugarcane was rapid. In this experiment, at the age of 6 days after inoculation in the field, the colonization percentage reached $9.67 \%$, which was significantly different from those without AMF inoculum (control).

However, with the increasing age of the plant (at the age of 7-11 weeks after transplantation), both treatments were not significantly different (Table 2). The condition was identified from the forming of arbuslucar and vesicle with no difference on mycorrhiza applications in both the nursery and the field, except in the control (Figure 2). In the control, the percentage of mycorrhiza infection reached $55.33 \%$ (Table 2 and Figure 1). 

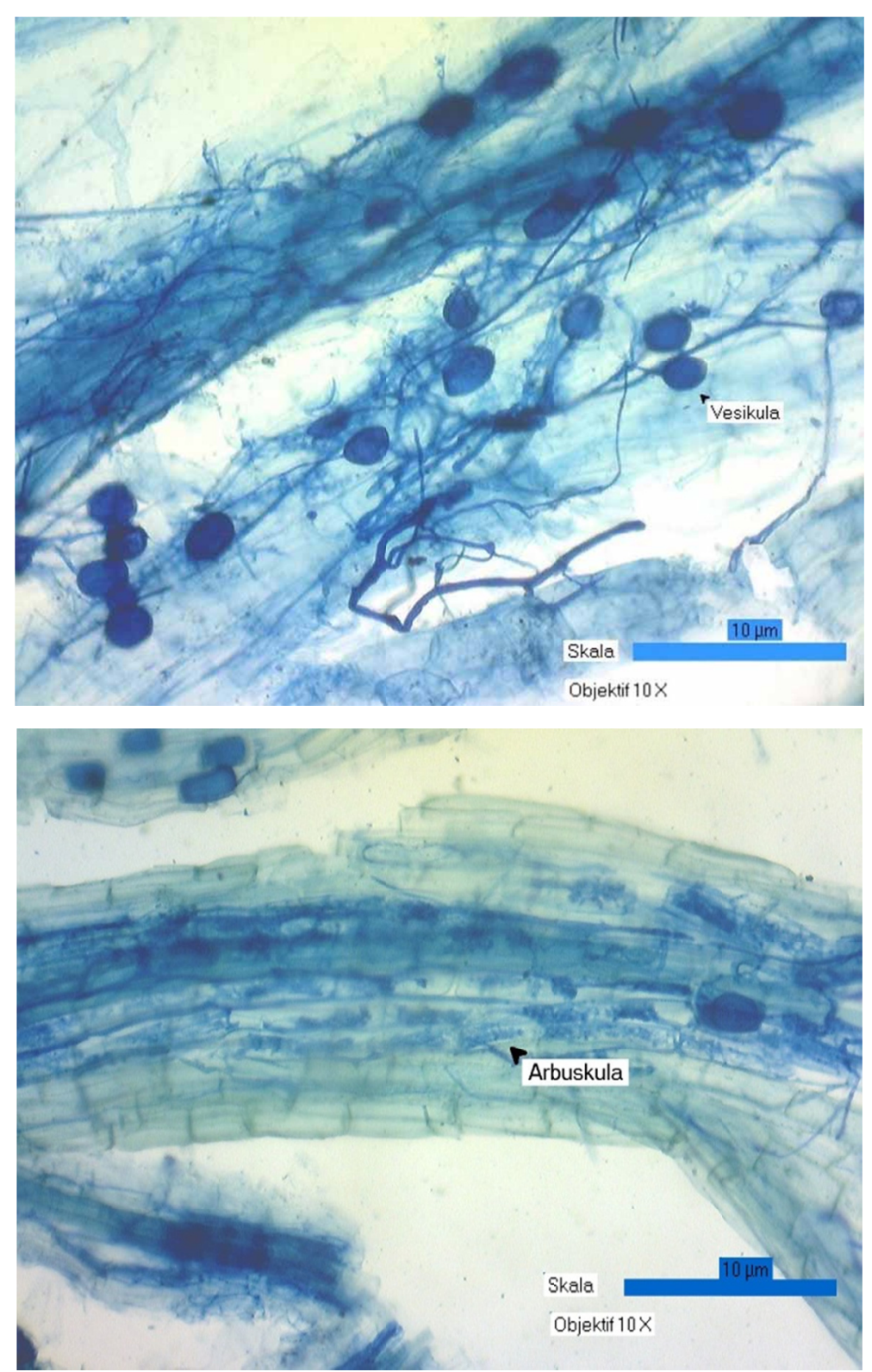

Figure 2. Mycorrhizal infection on sugarcane bud chips. Kidangkencana clone with AMF inoculum application at 6 weeks after transplantation.

\subsection{Physiological Performances}

\subsubsection{Photosynthetic Rate (Pn)}

There was an interaction between AMF inoculum application times and clones on the photosynthetic rate (Pn) (Table 3). The mycorrhizal application in the nursery significantly increased Pn in the Bululawang (BL) and VMC clones compared with without AMF inoculum (control) (Table 4). 
Table 3. Two-way ANOVA of clone and AMF inoculum application on $\mathrm{Pn}, \mathrm{Ci}$, chlorophyll content, and leaf area at the age of 5 weeks after transplantation

\begin{tabular}{llllllll}
\hline Source & $\mathrm{df}$ & $\mathrm{Pn}$ & $\mathrm{Ci}$ & Chorophyll a & Chorophyll b & Total Chorophyll & Leaf area \\
\hline Clone & 4 & 0.0002 & $<.0001$ & $<.0001$ & $<.0001$ & $<.0001$ & $<.0001$ \\
Mycorhiza & 2 & 0.0002 & 0.0028 & $<.0001$ & $<.0001$ & $<.0001$ & $<.0001$ \\
Interaction & 8 & 0.0107 & $<.0001$ & 0.0018 & 0.0060 & 0.0002 & $<.0001$ \\
$\mathrm{CV}(\%)$ & & 1.08 & 10.47 & 6.54 & 9.91 & 6.88 & 9.09 \\
\hline
\end{tabular}

Note. Numbers in the table represent the probability values.

\subsubsection{Intercellular $\mathrm{CO}_{2}$ Concentration $(\mathrm{Ci})$}

There was an interaction between AMF inoculum application times and clones on the intercellular $\mathrm{CO}_{2}$ concentration (Ci) (Table 3). The BL clone with the application in the nursery produced the highest $\mathrm{Ci}$, which was significantly different from all combined treatments except for the same clone with the application in the field (Table 4).

Table 4. Physiological performance of clones affected by the interaction between AMF inoculum application and clones at the age of 5 weeks after transplantation

\begin{tabular}{|c|c|c|c|c|c|c|}
\hline Clone & $\begin{array}{l}\text { AMF } \\
\text { application }\end{array}$ & $\begin{array}{l}\mathrm{Pn} \\
\left(\mu \mathrm{mol} \mathrm{CO} 2 / \mathrm{m}^{2} / \mathrm{S}\right)\end{array}$ & $\begin{array}{l}\mathrm{Ci} \\
(\mu \mathrm{mol} \mathrm{CO} / \mathrm{mol})\end{array}$ & $\begin{array}{l}\text { Chorophyll a } \\
(\mathrm{mg} / \mathrm{g})\end{array}$ & $\begin{array}{l}\text { Chorophyll b } \\
(\mathrm{mg} / \mathrm{g})\end{array}$ & $\begin{array}{l}\text { Total Chorophyll } \\
(\mathrm{mg} / \mathrm{g})\end{array}$ \\
\hline \multirow[t]{3}{*}{ PS864 } & In the nursery & $147.00 \mathrm{bcd}$ & $1323.3 \mathrm{e}$ & $0.270 \mathrm{bc}$ & 0.190 cde & $0.460 \mathrm{~b}$ \\
\hline & In the field & $147.00 \mathrm{bcd}$ & $1256.8 \mathrm{e}$ & $0.258 \mathrm{bc}$ & $0.173 \mathrm{de}$ & $0.430 \mathrm{bc}$ \\
\hline & Control & $144.75 \mathrm{de}$ & $1556.8 \mathrm{de}$ & $0.323 \mathrm{a}$ & $0.227 \mathrm{abc}$ & $0.550 \mathrm{a}$ \\
\hline \multirow[t]{3}{*}{ KK } & In the nursery & $145.00 \mathrm{de}$ & $1526.8 \mathrm{de}$ & $0.330 \mathrm{a}$ & $0.250 \mathrm{a}$ & $0.590 \mathrm{a}$ \\
\hline & In the field & $144.00 \mathrm{e}$ & $1540.0 \mathrm{de}$ & $0.280 \mathrm{~b}$ & 0.197 bcde & $0.470 \mathrm{~b}$ \\
\hline & Control & $145.00 . \mathrm{de}$ & $1480.0 \mathrm{de}$ & $0.335 \mathrm{a}$ & $0.248 \mathrm{a}$ & $0.598 \mathrm{a}$ \\
\hline \multirow[t]{3}{*}{ PS881 } & In the nursery & $145.75 \mathrm{cde}$ & $1980.0 \mathrm{bc}$ & $0.313 \mathrm{a}$ & $0.223 \mathrm{abcd}$ & $0.538 \mathrm{a}$ \\
\hline & In the field & $146.00 \mathrm{cde}$ & $1933.3 \mathrm{bc}$ & $0.320 \mathrm{a}$ & $0.240 \mathrm{abc}$ & $0.560 \mathrm{a}$ \\
\hline & Control & $144.75 \mathrm{de}$ & $1696.8 \mathrm{~cd}$ & $0.338 \mathrm{a}$ & $0.250 \mathrm{a}$ & $0.588 \mathrm{a}$ \\
\hline \multirow[t]{3}{*}{$\mathrm{BL}$} & In the nursery & $149.00 \mathrm{ab}$ & $2636.8 \mathrm{a}$ & $0.340 \mathrm{a}$ & $0.257 \mathrm{a}$ & $0.593 \mathrm{a}$ \\
\hline & In the field & $148.25 \mathrm{abc}$ & $2550.0 \mathrm{a}$ & $0.318 \mathrm{a}$ & $0.220 \mathrm{abcd}$ & $0.548 \mathrm{a}$ \\
\hline & Control & $146.00 \mathrm{cde}$ & $1643.3 \mathrm{~d}$ & $0.333 \mathrm{a}$ & $0.247 \mathrm{ab}$ & $0.578 \mathrm{a}$ \\
\hline \multirow[t]{3}{*}{ VMC } & In the nursery & $150.25 \mathrm{a}$ & $2203.3 \mathrm{~b}$ & $0.313 \mathrm{a}$ & $0.233 \mathrm{abc}$ & $0.548 \mathrm{a}$ \\
\hline & In the field & $145.00 \mathrm{de}$ & $2083.3 \mathrm{~b}$ & $0.240 \mathrm{c}$ & $0.160 \mathrm{e}$ & $0.400 \mathrm{c}$ \\
\hline & Control & $145.25 \mathrm{de}$ & $2210.0 \mathrm{~b}$ & $0.313 \mathrm{a}$ & $0.240 \mathrm{abc}$ & $0.570 \mathrm{a}$ \\
\hline
\end{tabular}

Note. The numbers followed by same letters in the same column are not significantly different based on Duncan's multiple range test at $\mathrm{p}<0.05$.

\subsubsection{Chlorophyll Content}

The interaction of the timing of AMF inoculum application with the clone was shown to have an influence on chlorophylls a, b, and the total chlorophyll content of leaf (Table 4). Only Bululawang (BL) clone with the application of mycorrhizae in the nursery stage has shown to have a higher content of chlorophylls a, $b$, and total chlorophyll compared to the control group.

The application of mycorrhizal inoculum which was applied in the nursery caused the content of chlorophylls a, $\mathrm{b}$ and total chlorophyll to be higher compared with application in the field. In addition, mycorrhizal inoculum that was applied in the field decreased the chlorophyll content significantly in KK and VMC clones (Table 4).

\subsection{Growth Performance}

\subsubsection{Leaf Area}

The treatment of AMF inoculum application times interacted with the clones and increased the leaf area significantly at the age of 11 weeks after transplantation (Table 3). The change in leaf area varied among the clones and interacted with the time of AMF inoculum application. 
Based on the results of this study, there was an interaction between clones and times of mycorrhizal application in the leaf area. The leaf area was significantly increased by mycorrhizal application in the nursery in case of Kidangkencana (KK), in the field in case of Bululawang (BL) or in both of them (VMC dan PS881) compared to control. It showed an increase of growth of shoots and the leaf area was restricted by a clone's genetic capacity (Table 5).

Table 5. Growth performance of clones affected by the interaction between AMF inoculum application and clones

\begin{tabular}{|c|c|c|c|c|c|c|c|c|c|}
\hline \multirow[t]{2}{*}{ Clone } & \multirow[t]{2}{*}{ AMF application } & \multicolumn{3}{|c|}{$\begin{array}{c}\mathrm{NAR}\left(\mathrm{g} / \mathrm{dm}^{2} / \text { day }\right) \\
\text { Ages: weeks after transplanting }\end{array}$} & \multicolumn{3}{|c|}{$\begin{array}{c}\text { CGR }\left(\mathrm{g} / \mathrm{dm}^{2} / \text { day }\right) \\
\text { Ages:weeks after transplanting }\end{array}$} & \multirow{2}{*}{$\begin{array}{c}\begin{array}{c}\text { Leaf area } \\
\left(\mathrm{cm}^{2}\right)\end{array} \\
30\end{array}$} & \multirow{2}{*}{$\begin{array}{l}\text { Stem weight } \\
\quad(\mathrm{g}) \\
30\end{array}$} \\
\hline & & 5 & 8 & 11 & 5 & 8 & 11 & & \\
\hline \multirow[t]{3}{*}{ PS864 } & In the nursery & $1.41 \mathrm{~b}-\mathrm{d}$ & $1.73 \mathrm{c}$ & $0.82 b-d$ & $0.060 \mathrm{~b}-\mathrm{c}$ & $0.27 \mathrm{c}$ & $0.40 \mathrm{c}$ & $2659.2 d$ & $73.0 \mathrm{ef}$ \\
\hline & In the field & $0.83 \mathrm{~cd}$ & $1.41 \mathrm{~cd}$ & $0.75 b-e$ & $0.027 \mathrm{ef}$ & $0.20 \mathrm{ef}$ & $0.32 \mathrm{~cd}$ & $2529.1 \mathrm{de}$ & $65.0 \mathrm{fg}$ \\
\hline & Control & $1.23 \mathrm{~b}-\mathrm{d}$ & $1.23 \mathrm{~d}-\mathrm{f}$ & $0.67 \mathrm{c}-\mathrm{e}$ & $0.047 \mathrm{c}-\mathrm{e}$ & $0.16 \mathrm{~g}$ & $0.31 \mathrm{~cd}$ & $2173.3 \mathrm{e}$ & $102 \mathrm{bc}$ \\
\hline \multirow[t]{3}{*}{$\mathrm{KK}$} & In the nursery & $1.46 \mathrm{bc}$ & $1.52 \mathrm{~cd}$ & $0.65 \mathrm{c}-\mathrm{e}$ & $0.047 \mathrm{c}-\mathrm{e}$ & $0.22 \mathrm{de}$ & $0.40 \mathrm{c}$ & $3489.1 \mathrm{c}$ & $74.0 \mathrm{ef}$ \\
\hline & In the field & $0.91 \mathrm{~b}-\mathrm{d}$ & $1.31 \mathrm{c}-\mathrm{f}$ & $0.60 \mathrm{de}$ & $0.033 \mathrm{ef}$ & $0.18 \mathrm{~g}$ & $0.30 \mathrm{~cd}$ & $1639.1 \mathrm{~g}$ & $91.0 \mathrm{~cd}$ \\
\hline & Control & $0.77 \mathrm{~cd}$ & $1.24 \mathrm{~d}-\mathrm{f}$ & $0.58 \mathrm{de}$ & $0.023 \mathrm{f}$ & $0.17 \mathrm{~g}$ & $0.28 \mathrm{~cd}$ & $2607.0 \mathrm{~d}$ & $59.0 \mathrm{~g}$ \\
\hline \multirow[t]{3}{*}{ PS881 } & In the nursery & $1.10 \mathrm{~b}-\mathrm{d}$ & $2.65 \mathrm{~b}$ & $1.10 \mathrm{~b}$ & $0.030 \mathrm{ef}$ & $0.28 \mathrm{bc}$ & $0.46 \mathrm{bc}$ & $2319.2 \mathrm{de}$ & $101 \mathrm{bc}$ \\
\hline & In the field & $1.50 \mathrm{~b}$ & $3.50 \mathrm{a}$ & $2.36 \mathrm{a}$ & $0.067 \mathrm{a}-\mathrm{c}$ & $0.53 \mathrm{a}$ & $0.96 \mathrm{a}$ & $2139.0 \mathrm{ef}$ & $101 \mathrm{bc}$ \\
\hline & Control & $0.79 \mathrm{~cd}$ & $0.90 \mathrm{f}$ & $0.34 \mathrm{e}$ & $0.047 \mathrm{c}-\mathrm{e}$ & $0.09 \mathrm{~h}$ & $0.11 \mathrm{e}$ & $1539.2 \mathrm{~g}$ & $91.0 \mathrm{~cd}$ \\
\hline \multirow[t]{3}{*}{$\mathrm{BL}$} & In the nursery & $1.17 \mathrm{~b}-\mathrm{d}$ & $1.35 \mathrm{c}-\mathrm{e}$ & $0.68 \mathrm{c}-\mathrm{e}$ & $0.058 \mathrm{~cd}$ & $0.29 b$ & $0.60 \mathrm{~b}$ & $5169.4 \mathrm{~b}$ & $129 \mathrm{a}$ \\
\hline & In the field & $1.23 \mathrm{~b}-\mathrm{d}$ & $1.23 \mathrm{~d}-\mathrm{f}$ & $0.51 \mathrm{de}$ & $0.038 \mathrm{~d}-\mathrm{f}$ & $0.23 \mathrm{~d}$ & $0.45 \mathrm{bc}$ & $7448.2 \mathrm{a}$ & $126 \mathrm{a}$ \\
\hline & Control & $0.72 \mathrm{~d}$ & $1.22 \mathrm{~d}-\mathrm{f}$ & $0.34 \mathrm{e}$ & $0.017 \mathrm{f}$ & $0.16 \mathrm{~g}$ & $0.18 \mathrm{de}$ & $3357.9 \mathrm{c}$ & $83.0 \mathrm{de}$ \\
\hline \multirow[t]{3}{*}{ VMC } & In the nursery & $2.20 \mathrm{a}$ & $1.24 \mathrm{~d}-\mathrm{f}$ & $1.04 \mathrm{bc}$ & $0.088 \mathrm{a}$ & $0.13 \mathrm{~h}$ & $0.32 \mathrm{~cd}$ & $1749.4 \mathrm{fg}$ & $108 \mathrm{~b}$ \\
\hline & In the field & $2.50 \mathrm{a}$ & $2.35 \mathrm{~b}$ & $2.12 \mathrm{a}$ & $0.083 \mathrm{ab}$ & $0.18 \mathrm{fg}$ & $0.41 \mathrm{c}$ & $1112.8 \mathrm{~h}$ & $92.0 \mathrm{bc}$ \\
\hline & Control & $2.30 \mathrm{a}$ & $0.95 \mathrm{ef}$ & $0.89 b-d$ & $0.060 \mathrm{c}$ & $0.07 \mathrm{j}$ & $0.16 \mathrm{de}$ & $1014.7 \mathrm{~h}$ & $67.0 \mathrm{fg}$ \\
\hline
\end{tabular}

Note. The numbers followed by same letters in the same column are not significantly different based on Duncan's multiple range test at $\mathrm{p}<0.05$.

\subsubsection{Net Assimilation Rate (NAR)}

PS864, KK, and BL clones with mycorrhizal application in the nursery has produced a NAR better compared to control (Table 5). The NAR reached the highest level at the age of 8 weeks after transplanting and declined thereafter.

Application of mycorrhiza in the nursery has produced the highest NAR at PS864, KK, PS881, and BL clones on the age of 5-11 weeks after transplanting. These results were unexpected by the level of the early colonies.

\subsubsection{Crop Growth Rate (CGR)}

CGR has increased linearly with the age of the plant up to the age of 11 weeks after transplanting. These results show an increase assimilates that produced the planting area per clump.The CGR has increased higher than controls and significantly different from control for each clone (Table 5).

\subsubsection{Biomass Weight of Stem}

The increase in the biomass weight of stem at the clones was significant by treatment of mycorrhiza (KK, BL, VMC clone) (Table 5). The increase in biomass was positively correlated with infection of mycorrhiza (\%) at the age of 5 weeks after transpanting, CGR, and NAR of the age of 11 weeks after transplanting with $r^{2}$ values of $0.54,0.91$, and 0.62 , respectively.

\section{Discussion}

Application mycorrhiza inoculum at the nursery provided an opportunity for the mycorrhizal fungi to colonize the roots soon. The mycorrhiza entered the roots through the lateral roots and sustained in the intra- and intercellular spaces which caused a change in the cell wall and established the colonization (Bellone \& de Bellone Silvia, 2012). The mycorrhiza formed vesicles that facilitated carbon exchange between the two 
organisms. Likewise, it formed arbuscules as organs of reproduction (Makarian et al., 2013; Schmitz \& Harrison, 2014; F. A. Smith \& S. E. Smith, 2011), thus increasing the infection percentage.

However, the increase of mycorrhizal infection will reach a constant. The development of mycorrhizal infection on the root has reached the optimum at the age of 7-11 weeks after transplanting. Sieverding (1991) said that arbuscular formed after 2-5 days of penetration of interwoven hyphae form strong, growing around plasmalema cells. In addition, the elongation of the fungus in the roots and rhizosphere passed the exponential phase, and has entered a phase of lower growth or balance, "plateu fase". According to Sieverding (1991), the exponential phase reaches a maximum of 40 days after infection.

On the treatment without mycorrhizal inoculation occurs mycorrhizal colonization. There may be indigenous mycorrhiza living in the control treatment area. From observations in the field, several types of indigenous mycorrhiza i.e. Glomus sp., Funneliformis sp., Acaulospora sp., Gigaspora sp., and Scutellospora sp. were observed. (Goltapeh, 2011) identified several genera of mycorrhiza in several clones of sugarcane, i.e. Glomus sp., Paraglomus sp., Pacispora sp., Kuklaspora sp. This is related to the level of dependence of mycorrhiza on plant. In the current study, the highest level of mycorrhizal dependence reached 94\%, whereas the clones PS864, KK, PS881, and VMC reached 88.7, 78, 80.7, and 49.4\%, respectively (unpublished data).

Mycorrhizal dependence according to Gendermann (1975) was defined as the degree of mycorrhizal plants' capability to grow normally in adjunction to improve soil fertility. Wu et al. (2014) stated that the higher the mycorrhizal dependence on plants, the higher the possibility of mycorrhizal infecting the plant roots. Furthermore, the higher level of mycorrhizal infection on the roots of plants indicated that the rate of absorption of nutrients by the mycelium of mycorrhiza was increased by the expansion of the root surface, and resulting in the dry weight of plants growth. The amount of carbon transferred to the rooting system is positively correlated with the presence of vesicles in the rooting system (Fitter et al., 1998).

In general, according to Javot et al. (2007), the development of infection was already seen 6 days after inoculation in the form of arbuscular population. However, there were differences of infection rate as determined by host plant such as in the age and performance of plants (Nasim et al., 2008) as well as in the type of host plant (Hindumati \& Reddy, 2011; Reece \& Bonham, 1978). Shaul-Keinan et al. (2002) reported that in tobacco, the infection percentage of mycorrhiza reached $40-50 \%$ at the age of 5 weeks after inoculation. Meanwhile, Aka-Kaçar et al. (2010) reported that mycorrhiza colony on the rooting system of cherry cuttings reached the highest at 16 weeks after inoculation.

Mycorrhizal inoculation early in the nursery increase the Pn in some clones ( $\mathrm{Bl}$ and VMC). Several researches showed that plants inocculated with mycorrhiza had a high Pn (Birhane et al., 2012; Masri et al., 1999). A better physiological capacity in symbiosis with arbuscular mycorrhiza (AM) is closely linked with an increased uptake of P and N (Corradi \& Bonfante, 2012; Jan et al., 2014; S. E. Smith \& F. A. Smith, 2012), also $\mathrm{Mg}^{2+}$, $\mathrm{K}^{+}$, and $\mathrm{Ca}^{2+}(\mathrm{Wu} \& \mathrm{Xia}, 2006)$. The $\mathrm{N}$ and $\mathrm{Mg}$ elements are needed for photosynthesis, while the $\mathrm{K}$ element has a role in stomatal adjustment. $\mathrm{Ca}$ is located in the middle lamella as calcium pectate that helps promote resistance against pathogenic fungi (Jamal et al., 2005). Thus, genetically BL and VMC clones have better photosynthetic capacity in symbiosis with mycorrhiza.

The sugarcane clone with high Pn tended to show drought tolerance like other physiological parameter such as photosystem II (Ф PS II), and higher water content of leaf (Graca et al., 2010; Lu \& Zhang, 1999; Zhao et al., 2010). Clones with high Pn have a special protein expression called "heat shock protein", which is a protein in light reaction; chlorophylls a, chlorophylls b formation, and higher transfer electron (Almeida et al., 2013; Ngamhui et al., 2012).

Mycorrhizal inoculation early in the nursery significantly increased Ci in BL clones. Zhao et al. (2010) reported that the $\mathrm{Ci}$ of sugarcane leaves increased significantly when the plants were stressed by drought, along with a decrease in $\mathrm{Pn}$ and transpiration. The high $\mathrm{Ci}$ of sugarcane leaves when stressed with drought showed that sugarcane was more efficient in utilizing limited $\mathrm{CO}_{2}$ by decreasing stomatal conductivity and Pn (Almeida et al., 2013). In such a condition, $\mathrm{Ci}$ in the leaf cell will become higher due to the removal of maleic acid in the bundle sheat cell (Goatly et al., 1975; Langdale, 2011). High increase of $\mathrm{CO}_{2}(102.7 \%$ above equilibrium) is used by sugarcane plants to increase the photosynthetic rate by $30 \%$, plant height by $17 \%$, and sugarcane biomass by $40 \%$ (De Souza et al., 2008). Vu and Allen (2009) reported that two times increases of $\mathrm{CO}_{2}$ concentration at a temperature of $6{ }^{\circ} \mathrm{C}$ caused a significant increase in the leaf area $(50 \%)$, the dry weight of leaf $(26 \%)$, the dry weight of the stem (84\%), the juice volume of the stem (124\%) compared with the control. Because the $\mathrm{BL}$ shows high $\mathrm{Ci}$ on mycorrhizal treatment in the nursery, it indicates that this clone is more tolerant in dry land. 
The higher content of chlorophyll in sugarcane leaf in several clones without mycorrhiza was indicating that the chlorophyll content of leaves of plants genetically influenced by genetic factor (Table 3). According to Medeiros et al. (2013), chlorophyll content of sugarcane is determined by varities. According to Zhao et al. (2005), chlorophyll content is determined more by the content of $\mathrm{N}$ than $\mathrm{P}$, and $\mathrm{K}$. Meanwhile, the presence of mycorrhizae tends to increase the uptake of P for plants (Schachtman et al., 1998; S. E. Smith \& F. A. Smith, 2012).

The application of mycorrhizal since in the nursery also significantly increases the leaf area. Several researchers showed that mycorrhizal application significantly increased the leaf area in comparison with that of without mycorrhizal application (Al-Karaki \& Clark, 1999; Melo et al., 1999; Gomez et al., 1999; Miranda et al., 2011). Besides the influence of mycorrhiza, the sugarcane leaf area is determined by genetic factors of clone.

On the increase in leaf area, besides being affected by the shoots activity, the increase in leaf area significantly indicated an increase in roots activity. It is based on the difference in the growth of sugarcane shoots that is directly determined by the capacity of the rooting system (Smith et al., 2005; Ohashi et al., 2015). The sugarcane growth was consistent with the functional equalibrium between roots and shoots (Smith et al., 1999).

Mycorrhizal applications also significantly increased the NAR on several clones (PS864, PS881, and VMC) than without mycorrhizal application. The influence was mainly at the age of 8 and 11 weeks after transplanting or 3-4 months after planting. From the results of this study, the NAR at the age of 11 weeks after transplanting was positive with infection of mycorrhiza (\%) with $\mathrm{r}^{2}$ values of 0.38 . These results are consistent with Miranda et al. (2011) reported that NAR of cape gooseberry has increased in early growth as a result of early growth and leaf formation, especially in plants inoculated with mycorrhiza.

NAR of clone VMC decreased at the age of 8 weeks, which suggested a drought stress. Erdei \& Taleisnik (1993) argued that NAR was decreased due to the effect of dryland stress. Drought stress has decreased stomatal conductivity, relative water content (RWC), as well as the rate of photosynthesis (Pn) (De Almeida Silva et al., 2013; Graca et al., 2010). Therefore, this has resulted in assimilating the resulting lower. Meanwhile in PS864, KK, PS881, and BL clones, the decline of NAR occurred later at the age of 9-10 weeks after transplanting. It showed that this clone was more tolerant on dry land compared with VMC.

Early mycorrhizal applications in the nursery significantly increased the CGR (PS864, KK, BL, and VMC clones). The clones with higher CGR with the application of mycorrhiza in the nursery stage was an indication of the adequate mutualistic interaction between mycorrhiza, and the plants which led to the increase of ratio dry matter in planted area. This indicates that the presence of mycorrhizal colonization in roots increases plant growth with a positive correlation $\mathrm{r}^{2}$ values of 0.38 . It refers to Chattha et al. (2007) who argued that the efficient utilization of applied inputs in a particular set of environments is reflected by the crop growth rate (CGR). Mycorrhizae which increased sugarcane CGR reported by Abdel-Fattah et al. (2014) a significantly increased rate of leaf area, shoot dry weight and root dry weight in the application of mycorrhiza. Shorgum crop increased the leaf area growth rate at $0.9 \mathrm{~g}$ inoculation mycorrhizal inoculum (Syvertsen \& Graham, 1990). Miranda et al. (2011) reported a plant Physalis peruviana L. inoculated mycorrhiza has improved the CGR (dry weight) 7\% higher than control.

The increase of CGR may be due to the fact that mycorrhiza increased the absorption of carbohydrates (hexoses) of plants to the mycorrhiza in root (Pfeffer et al., 1999). Furthermore, Mycorrhiza would increase the sink capacity in the rooting system, such as an increase in soluble sugars in the roots (Feng et al., 2002), soluble proteins, the concentration of $\mathrm{N}$ and $\mathrm{P}$ on rooting cane (Abdel-Fattah et al., 2014). The growth of sugarcane shoot is directly determined by the capacity of the rooting system (Smith et al., 2005; Ohashi et al., 2015).

The increase of CGR on the sugarcane is influenced by the growth phase and different planting techniques (Chattha et al., 2007). Morever, Chattha et al. (2007) reported that the maximum CGR was recorded in active growth stage (4 months after planting) and sowing in $120 \mathrm{~cm}$ apart trenches. At the age of 75 days after sowing is the tillering phase so that CGR is used to tillering (Samui et al., 2003). Meanwhile in the results of this study, CGR was still increasing at age of 11 weeks after transplanting or 4 months after planting.

There was interaction between clones and timing of mycorrhiza application on stem weight (stem biomass). However, the presence of these interactions shows the difference in the ability of clones in the physiological processes by the presence of mycorrhizae that can be termed as mycorrhizal responsiveness. From several researches, components of the leaves and stems of sugarcane are influenced more by genetic factors (Aboagye et al., 2003; Silva et al., 2008). Meanwhile, the mycorrhizal responsiveness is one unit result arising from the interaction between plants and mycorrhizal genus, in this case the dry weight or biomass (Baon et al., 1993; Janos, 2007). 
Bellone and de Bellone Silvia (2012) reported that mycorrhizal inocculation of Glamos intrarradix and Azospirillum brasilense significantly increased the sugarcane biomass 20 days after inocculation. In addition, the increase in biomass is due to a significant increase in the allocation of carbohydrate uptake into the roots (Morgan et al., 2005; Valle et al., 2009; Sgrott et al., 2012). The amount of carbon transferred to the rooting system is positively correlated with the presence of vesicles in the rooting system (Fitter et al., 1998). The vesicles facilitate the exchange of carbon between the host plant and mycorrhiza (Makarian et al., 2013; F. A. Smith \& S. E. Smith, 2011).

In the current study, increasing in biomass was positively correlated with infection of mycorrhiza (\%) at the age of 5 weeks after transpanting, CGR, and NAR at the age of 11 weeks after transplanting with $\mathrm{r}^{2}$ values of 0.54 , 0.91 , and 0.62 , respectively.

\section{Conclusion}

In increasing the growth of sugarcane in dry land, the application arbuscular mycorrhiza since the nursery has accelerated the infection by $41.33 \%$ ( 1 week after transplantation) and has increased the percentage of mycorrhizal infection by $83.33 \%$ ( 5 weeks after transplantation). There are differences in physiological and growth performance of clones by the effect of timing of mycorrhizal application. Bululawang with mycorrhizal applications in the nursery tend to have better physiological performance such as chlorophylls a, b, and total chlorophyll, Photosynthesis rate (Pn), intercellular $\mathrm{CO}_{2}$ concentration (Ci), leaf area, and the weight of stem biomass. Mycorrhizal application in the nursery produces the highest of NAR on the PS864 and BL clones, and the highest of CGR on the PS864, KK, and BL clones.

\section{References}

Abdel-Fattah, G. M., Asrar, A. A., Al-Amri, S. M., \& Abdel-Salam, E. M. (2014). Influence of arbuscular mycorrhiza and phosphorus fertilization on the gas exchange, growth and phosphatase activity of soybean (Glycine max L.) plants. Photosynthetica, 52(4), 581-588. https://doi.org/10.1007/s11099-014-0067-0

Aboagye, I. M., Terauchi, T., \& Matsouka, M. (2003). Characterization and preliminary evaluation of factors for early growth in sugarcane. Ghana Jnl Agric. Sc., 36, 121-131. https://doi.org/10.4314/gjas.v36i.1.2071

Aka-Kaçar, Y., Akpinar, Ç., Agar, A., Yalçin-Mendi, Y., Serçe, S., \& Ortaş, I. (2010). The effect of mycorrhiza in nutrient uptake and biomass of cherry rootstocks during acclimatization. Romanian Biotechnological Letters, 15(3), 5246-5252.

Al-Karaki, G. N., \& Clark, R. B. (1999). Varied rates of mycorrhizal inoculums on growth and nutrient acquisition by barley growth with drought stress. Journal of Plant Nutrition, 22, 1775-1784. https://doi.org/10.1080/01904169909365753

Almeida, C. M. A., Donato, V. M. T. S., Amaral, D. O. J., Lima, G. S. A., Brito, G. G., Lima, M. M. A., ... Silva, M. J. (2013). Differential gene expression in sugarcane induced by salicylic acid and under water deficit conditions. Agricultural Science Research Journal, 3(1), 36-44.

Baon, J. B., Smith, S. E., \& Alston, A. M. (1993). Mycorrhizal responses of barley cultivars differing in P efficiency. Plant Soil, 157(1), 97-105. https://doi.org/10.1007/BF02390231

Basnayake, J., Jackson, P. A., Inman-Bamber, N. G., \& Lakshmanan, P. (2012). Sugarcane for water-limited environments. Genetic variation in cane yield and sugar content in response to water stress. Journal of Experimental Botany, 63(2), 695-709. https://doi.org/10.1093/jxb/ers251

Bellone, C. H., \& de Bellone Silvia, C. (2012). Interaction of Azospirillum brasilense and Glomus intrarradix in sugarcane roots. Indian Journal of Microbiology, 52(1), 70-75. https://doi.org/10.1007/s12088-011-0208-0

Birhane, E., Sterck, F. J., Fetene, M., Bongers, F., \& Kuyper, T. W. (2012). Arbuscular mycorrhizal fungi enhance photosynthesis, water use efficiency, and growth of frankincense seedlings under pulsed water availability conditions. Oecologia, 169(4), 895-904. https://doi.org/10.1007/s00442-012-2258-3

Boyle, R. K., McAinsh, M., \& Dodd, L. C. (2015). Stomatal closure of Pelargonium $\times$ hortorum in response to soil water deficit is associated with decreased leaf water potential only under rapid soil drying. Physiologia Plantarum, 156(1), 84-96. https://doi.org/1111/ppl.12346

Central Bureau of Statistics. (2013). Agriculture and mines. Publication of CBS. Retrieved from http://www.bps.go.id/hasil_publikasi

Chattha, M. U., Ali, A., \& Bilal, M. (2007). Influence of planting techniques on growth and yield of spring planted sugarcane (Saccharum officinarum L.). Pakistan Journal of Agricultural Sciences, 44, 452-456 
Corradi, N., \& Bonfante, P. (2012). The Arbuscular mycorrhizal symbiosis: Origin and evolution of a beneficial plant infection. PLoS Pathogens, 8(4), 8-10. https://doi.org/10.1371/journal.ppat.1002600

De Almeida Silva, M., Jifon, J. L., dos Santos, C. M., Jadoski, C. J., \& da Silva, J. A. G. (2013). Photosynthetic capacity and water use efficiency in sugarcane genotypes subject to water deficit during early growth phase. Brazilian Archives of Biology and Technology, 56(5), 735-748. https://doi.org/10.1590/S1516-891320130 00500004

De Souza, A. P., Gaspar, M., Da Silva, E. A., Ulian, E. C., Waclawovsky, A. J., Nishiyama, M. Y., ... Buckeridge, M. S. (2008). Elevated $\mathrm{CO}_{2}$ increases photosynthesis, biomass and productivity, and modifies gene expression in sugarcane. Plant, Cell and Environment, 31(8), 1116-1127. https://doi.org/10.1111/ j.1365-3040.2008.01822.x

Douds, D. D., Chaiyasen, A., Vasquez, L. R., \& Wertheim, F. S. (2014). On farm production of arbuscular mycorrhizal fungus inoculation in compost and vermiculite mixtures: Results of on farm demonstrations and impact of compost microbiological quality. Journal of the NACAA, 7(2), 1-7. Retrieved from $\mathrm{http}: / /$ www.nacaa.com/journal/index.php?jid=444

Erdei, L., \& Taleisnik, E. (1993). Changes in water relation parameters under osmotic and salt stresses in maize and sorghum. Physiol. Plant, 89(2), 381-387. https://doi.org/10.1111/j.1399-3054.1993.tb00170.x

Feng, G., Zhang, F. S., Li, X. L., Tian, C. Y., Tang, C., \& Rengel, Z. (2002). Improved tolerance of maize plants to salt stress by arbuscular mycorrhiza is related to higher accumulation of soluble sugars in roots. Mycorrhiza, 12(4), 185-190. https://doi.org/10.1007/s00572-002-0170-0

Fitter, A. H., Graves, J. D., Watkins, N. K., Robinson, D., \& Scrimgeour, C. (1998). Carbon transfer between plants and its control in networks of arbuscular mycorrhizas. Functional Ecology, 12(3), 406-412. https://doi.org/10.1046/j.1365-2435.1998.00206.x

Fundora, O., Vidaurre, M., Torrecilla, Y., Ríos, C., \& Löbermann, B. E. (2008). Fertilizing effects of combined application of sugarcane ash with mycorrhiza fungi and compost in different cuban soils. Universidad Central de Las Villas, Facultad Ciencias Agropecuarias, Carretera Camajuaní, Cu 54830 Santa Clara, Cuba. Retrieved from http://www.tropentag.de/2010/abstracts/full/695.pdf

Gana, A. K. (2011). Cowdung: Soil amendment agent for the sandy upland sugarcane ecology in Nigeria. Journal of Agricultural Technolgy, 7(2), 497-505.

Gerdemann, J. W. (1975). Vesicular-arbuscular mycorrhizae. In J. G. Torrey \& D. T. Clarkson (Eds.), Development and fungtion of roots (pp. 575-591). Academic Press, London.

Goatly, M. B., Coombs, J., \& Smith, H. (1975). Development of C4 photosynthesis in sugarcane: Change in properties of phosphoenolpyruvate carboxylase during growing. Planta (Berl.), 125, 15-24. https://doi.org/10.1007/BF00388869

Goltapeh, E. M. (2011). Diversity of Arbuscular Mycorrhizal Fungi associated with common sugarcane varieties in Iran. International Journal of Agricultural Technology, 7(4), 1017-1022.

Gomez, A. L., Davies, F. T. J., Portugal, U. O., Duray, S. A., \& Phavaphutanon, L. (1999). Influence of phosphorus and endomycorrhiza (Glomus intraradices) on gas exchenge and plant growth of chile ancho pepper (Capsicum annuum L. cv. San Luis). Photosynthetica, 36(3), 441-449. https://doi.org/10.1023/ A:1007032320951

Goud, V. V. (2011). Susteinable sugarcane initiative, SSI - A methodology for improving yields (pp. 9-12). First National Seminar on Sustainable Sugarcane Initiative, Seminar Papers. AgSri, Sugarcane Breeding Institute (SBI) and Natural Resource Management Center (NRMC), Tamil Nadu, India. Retrieved from http://www.agsri.com/.../SSI\%20Seminar\%20Papers\%20-\%20Draft.p

Graca, J. P., Rodigues, F. A., Farias, J. R. B., Oliveira, M. C. N., Campo, C. B. H., \& Zingaretti, S. M. (2010). Physiological parameters in sugarcane cultivarssubmitted to water deficit. Braz. J. Plant Physiol, 22(3), 187-197. https://doi.org/10.1590/S1677-04202010000300006

Hindumathi, A., \& Reddy, B. N. (2011). Annals of nuclear medecine and molecular imaging occurrence and distribution of arbuscular mycorrhizal fungi and microbial flora in the rhizosphere soils of mungbean [Vigna radiate (L.) wilezek] and soybean [Glycine maz (L.) Merr.] from Adilabad, Nizamabad and Karimnagar districts of Andhra Pradesh state, India. Advance in Bioscience and Biotechnology, 2, 275-286. Retrieved from http://www.airitilibrary.com/Publication/alDetailedMesh?docid=21568456-201108-2012101 
60007-201210160007-275-286

Hongwei, B. T., Chenglin, D., \& Liuqiang, Z. (2000). Effect of magnesium fertilizer on sustaining upland agricultural development in guangxi province. Better Crops International, 14(2), 1-3. Retrieved from https://www.researchgate.net/.../265741125

Jain, R., Solomon, S., Shrivastara, A. K., \& Chandra, A. (2010). Sugarcane budchips: A promising seed materials. Sugar Tech, 12, 67-69. https://doi.org/10.1007/s12355-010-0013-9

Jamal, S. F., Cadet, P., Rutherford, R. S., \& Straker, C. J. (2005). Effect of mycorrhiza on the nutrient uptake of sugarcane. Proceedings-of-the-78th-Annual-Congress-of-South-African-Sugar-Technologists (pp. 343-348). South Africa: University of the Witwatersrand, Johannesburg.

Jan, B., Ali, A., Wahid, F., Noor, S., \& Shah, M. (2014). Effect of arbuscular mycorrhiza fungal inoculation with compost on yield and phosphorous uptake of berseem in alkaline calcareous soil. American Journal of Plant Sciences, 5(13), 1359-1369. https://doi.org/10.4236/ajps.2014.513213

Janos, D. P. (2007). Plant responsiveness to mycorrhizas differs from dependence upon mycorrhizas. Mycorrhiza, 17, 75-91. https://doi.org/10.1007/s00572-006-0094-1

Javot, H., Pumplin, N., \& Harrison, M. J. (2007). Phosphate in the arbuscular mycorrhizal symbiosis: Transport properties and regulatory roles. Plant, Cell and Environment, 30(3), 310-322. https://doi.org/10.1111/ j.1365-3040.2006.01617.x

Kumar, V. M., \& Suresh, K. (2011). Studies on physiological aspect of growth, quality and yield of bud chip technology in sugarcane (pp. 44-46). First National Seminar on Sustainable Sugarcane Initiative, Seminar Papers. AgSri, Sugarcane Breeding Institute (SBI) and Natural Resource Management Center (NRMC), Tamil Nadu, India. Retrieved from http://www.agsri.com/.../SSI\%20Seminar\%20Papers\%20-\%20Draft.p...

Langdale, J. A. (2011). $\mathrm{C}_{4}$ Cycles: Past, Present, and Future Research on $\mathrm{C}_{4}$ Photosynthesis. The Plant Cell, 23(11), 3879-3892. https://doi.org/10.1105/tpc.111.092098

Lawlor, D. W., \& Cornic, G. (2002). Photosynthetic carbon assimilation and associated metabolism in relation to water deficits in higher plants. Plant, Cell \& Environment, 25(2), 275-294. https://doi.org/10.1046/ j.0016-8025.2001.00814.x

Makarian, H., Poozesh, V., \& Asghari, H. R. (2013). Effect of arbuscular mycorrhizal fungi on plant growth under soil applied herbicide. International Journal of Agronomy and Plant Production, 4(9), 2158-2165. Retrieved from https://www.cabdirect.org/?target=\%2fcabdirect $\% 2$ fabstract\%2f20133313427

Masri, M., Azizah, H., Razi, I. M., \& Mamat, A. S. (1999). Physiological responses of mycorrhizal and uninoculated seedlings of mangosteen (Garcinia mangostana L.) to water depletion and subsequent rewatering. J. Trop. Agric. and Fd. Sc., 27(1), 17-26.

Medeiros, D. B., Ciríaco, E., Silva, D., Jurema, R., Nogueira, M. C., Teixeira, M. M., \& Silveira Buckeridge, M. (2013). Physiological limitations in two sugarcane varieties under water suppression and after recovering. Theoretical and Experimental Plant Physiology, 25(3), 213-222. https://doi.org/10.1590/S2197-00252013 000300006

Melo, A. M. Y., Maia, L. C., Sanggin, O. J. J., Filho, J. M. L., \& Milo, N. F. (1999). Effect of arbuscular mycorrhizal fungi on the acclimatization of micropropagated banana planlets. Mycorrhiza, 9, 119-123. https://doi.org/10.1007/s005720050009

Miranda, D., Fischer, G., \& Ulrichs, C. (2011). The influence of arbuscular mycorrhizal colonization on the growth parameters of cape gooseberry (Physalis peruviana L.) plants grown in a saline soil. Journal of Soil Science and Plant Nutrition, 11(2), 18-U126. https://doi.org/10.4067/S0718-95162011000200003

Morgan, J. A. W., Bending, G. D., \& White P. J. (2005). Biological costs and benefits to plant-microbe interactions in the rhizosphere. Journal of Experimental Botany, 56(417), 1729-1739. https://doi.org/10.1093/jxb/eri205

Morgan, J. A. W., Bending, G. D., \& White, P. J. (2005). Biological costs and benefits to plant-microbe interactions in the rhizosphere. Journal of Experimental Botany, 56(417), 1729-1739. https://doi.org/10.1093/jxb/eri205

Nasim, G., Ali, A., Munawar, A., \& Bajwa, R. (2008). Seasonal dynamics of AM Fungi in Sugarcane (saccharum officinarum L. CV. SPF-213) in relation to red rot (Colletotrichum falcatum) disease from Punjab, Pakistan. Pakistan Journal of Botany, 40(6), 2587-2600. 
Natarajan, U. S. (2011). Tillering in SSI-emergence, factor affecting, constraints, and solution. Bud chip nurseries-history, method of raising, results of germination studies (pp. 21-23). First National Seminar on Sustainable Sugarcane Initiative, Seminar Papers. AgSri, Sugarcane Breeding Institute (SBI) and Natural Resource Management Center (NRMC), Tamil Nadu, India. Retrieved fromn http://www.agsri.com/.../SSI\%20Seminar\%20Papers\%20-\%20Draft.p

Ngamhui, N. O., Akkasaeng, C., Zhu, Y. J., Tantisuwichwong, N., Roytrakul, S., \& Sansayawichai, T. (2012). Differentially expressed proteins in sugarcane leaves in response to water deficit stress. Plant OMICS, 5(4), 365-371.

Ohashi, A. Y. P., de Matos Pires, R. C., Ribeiro, R. V., \& de Oliveira Silva, A. L. B. (2015). Root growth and distribution in sugarcane cultivars fertigated by a subsurface drip system. Bragantia, 74(2), 1-9. https://doi.org/10.1590/1678-4499.0295

Omoto, G., Abayo, G. O., \& Jamoza, J. E. (2007). Effect of delayed planting of seedcane on sugarcane germination, growth rate and yield. Kenya Sugar Research Foundation. Kisumu-Kenya. Retrieved from https://www.yumpu.com/en/document/view/24269929/1-effect-of-delayed-planting-of-seedcane-on

Onoleo, F., Vidaurre, M., Torrecilla, Y., Ríos, C., \& Löbermann, B. E. (2008). Fertilizing effects of combined application of sugarcane ash with mycorrhiza fungi and compost in different cuban soils. Universidad Central de Las Villas, Facultad Ciencias Agropecuarias, Carretera Camajuaní, Cu 54830 Santa Clara, Cuba. Retrieved from http://www.tropentag.de/2010/abstracts/full/695.pdf

Pasternak, D., \& Wilson, G. L. (1974). Differing effect of water deficit on net photosynthesis of intact and excised sorghum leaves. New Phytol., 73, 847-850. https://doi.org/10.1111/j.1469-8137.1974.tb01313.x

Pfeffer, P. E., Douds Jr, D. D., Bécard, G., \& Shachar-Hill, Y. (1999). Carbon uptake and the metabolism and transport of lipids in an arbuscular mycorrhiza. Plant Physiol, 120(2), 587-598. https://doi.org/10.1104/pp.120.2.587

Plett, J. M., Kemppainen, M., Kale, S. D., Kohler, A., Legué, V., Brun, A., .. Martin, F. (2011). A secreted effector protein of laccaria bicolor is required for symbiosis development. Current Biology, 21(14), 1197-1203. https://doi.org/10.1016/j.cub.2011.05.033

Rani, U. T., Balaguravaiah, D., Rao, V. K., Laxmi, B. M., \& Reddy, V. V. D. (2013). Effect of different levels of phosphorus on yield and quality of sugarcane as influenced by cane trash and mycorrhizae. Ind. J. Sci. Res. and Tech., 1(1), 61-65.

Reece, P., \& Bonham, C. D. (1978). Frequency of endomycorrhizal infection in grazed and ungrazed blue grama plants. Journal of Range Management, 31, 149-151. https://doi.org/10.2307/3897667

Samui, R. P., John, G., \& Kulkarni, M. B. (2003). Impact of weather on yield of sugarcane at different growth stages. Jour. Agric. Physics, 3(1-2), 119-125. Retrieved from http://agrophysics.in/Published/2003/ 2003-paper-20.pdf

Schachtman, D. P., Reid, R. J., \& Ayling, S. M. (1998). Phosphorus uptake by plants: From soil to cell. Plant Physiology, 116(2), 447-453. https://doi.org/10.1104/pp.116.2.447

Schmitz, A. M., \& Harrison, M. J. (2014). Signaling events during initiation of arbuscular mycorrhizal symbiosis. Journal of Integrative Plant Biology, 56(3), 250-261. https://doi.org/10.1111/jipb.12155

Serna-Cock, L., Arias-Garcia, C., \& Valencia Hernandez, L. J. (2011). Efecto de la biofertilizacion sobre el crecimiento en maceta de plantas de caña de azucar (Saccharum officinarum). Biotecnologia En El Sector Agropecuario Y Agroindustrial, 9(2), 85-95.

Sgrott, A. S., Booz, M., Pescador, R., Heck, C. T., \& Stürmer, L. S. (2012). Arbuscular mycorrhizal inoculation increases biomass of euterpe edulis and archontophoenix alexandrae after two years under field conditions. R. Bras. Ci. Solo, 36, 1103-1112. https://doi.org/10.1590/S0100-06832012000400005

Shaul-Keinan, O., Gadkar, V., Ginzberg, I., Grunzweig, J. M., Chet, I., Elad, Y., ... Kapulnik, Y. (2002). Hormone concentrations in tobacco roots change during arbuscular mycorrhizal colonization with Glomus intraradices. New Phytologist, 154(2), 501-507. https://doi.org/10.1046/j.1469-8137.2002.00388.x

Sieverding, E. (1991). Vesicular-arbuscular mycorrhiza management in tropical agrosystem (pp. 27-36). Deutsche Gesellschaft für Technische Zusammenarbeit (GTZ) GmbH. Technical Cooperation-Federal Republic of Germany.

Silva, M. D. A., Silva, J. A. G. Da, Enciso, J., Sharma, V., \& Jifon, J. (2008). Yield components as indicators of 
drought tolerance of sugarcane. Scientia Agricola, 65(December), 620-627. https://doi.org/10.1590/S010390162008000600008

Smith, D. M., Inman-Bamber, N. G., \& Thorburn, P. J. (2005). Growth and function of the sugarcane root system. Field Crops Research, 92(2-3), 169-183. http:// doi.org/10.1016/j.fcr.2005.01.017

Smith, F. A., \& Smith, S. E. (2011). What is the significance of the arbuscular mycorrhizal colonisation of many economically important crop plants? Plant Soil, 348, 63-79. http://doi.org/10.1007/s11104-011-0865-0

Smith, J. P., Lawn, R. J., \& Nable, R. Q. (1999). Investigations into the root:shoot relationship of sugarcane, and some implications for crop productivity in the presence of sub-optimal soil conditions. Proceedings of the Australian Society of Sugarcane Technologists, 21, 108-113. Retrieved from http://www.assct.com.au/ media/pdfs/1999_pa_ag17.pdf

Smith, S. E., \& Smith, F. A. (2012). Fresh perspectives on the roles of arbuscular mycorrhizal fungi in plant nutrition and growth. Mycologia, 104(1), 1-13. https://doi.org/10.3852/11-229

Smth, A. M., \& Harrison, M. J. (2014). Signaling events during initiation of arbuscular mycorrhizal symbiosis. Journal of Intergrative Plant Biology, 56(3), 250-261.https://doi.org/10.1111/jipb.12155

Surendran, U., \& Vani, D. (2013). Influence of arbuscular mycorrhizal fungi in sugarcane productivity under semiarid tropical agro ecosystem in India. International Journal of Plant Production, 7(2), 269-277. https://www.researchgate.net/publication/288282492

Valle, C. H., Esqueda, M., Soto, E. M. V., \& Castellanos, A. E. (2009). Water stress tolerance in plant arbuscular mycorrhizal fungi interaction: Energy metabolism and physiology. Rev. Fitotec. Mex, 32(4), 265-271. Retrieved from http://www.citeulike.org/user/IAI/article/9397591

Vu, J. C. V., \& Allen, L. H. (2009). Stem juice production of the C4 sugarcane (Saccharum officinarum) is enhanced by growth at double-ambient $\mathrm{CO}_{2}$ and high temperature. Journal of Plant Physiology, 166, 1141-1151. https://doi.org/10.1016/j.jplph.2009.01.003

Wintermants, J. F. G. M., \& Demonts. (1965). Spectrophotometric characteristics of chlorophylls a and b their pheophytins in etanol. Biochim. Biophys. Acta (Amst.), 109, 448-453. https://doi.org/10.1016/09266585(65)90170-6

Wu, Q. S., \& Xia, R. X. (2006). Arbuscular mycorrhizal fungi influence growth, osmotic adjustment and photosynthesis of citrus under well-watered and water stress conditions. Journal of Plant Physiology, 163(4), 417-25. https://doi.org/10.1016/j.jplph.2005.04.024

Wu, Q. S., Huang, Y. M., Li, Y., Nasrullah, \& He, X. H. (2014). Contribution of arbuscular mycorrhizas to glomalin-related soil protein, soil organic carbon and aggregate stability in citrus rhizosphere. International Journal of Agriculture and Biology, 16(1), 207-212.

Zhao, D., Glaz, B., \& Comstock, J. C. (2010). Sugarcane response to water-deficit stress during early growth on organic and sand soils. American Journal of Agricultural and Biological Science, 5(3), 403-414. https://doi.org/10.3844/ajabssp.2010.403.414

Zhao, D., Glaz, B., \& Comstock, J. C. (2013). Sugarcane leaf photosynthesis and growth characters during development of water-deficit stress. Crop Science, 53(3), 1066-1075. https://doi.org/10.2135/ cropsci2012.09.0554

Zhao, D., Reddy, K. R., Kakani, V. G., \& Reddy, V. R. (2005). Nitrogen deficiency effects on plant growth, leaf photosynthesis, and hyperspectral reflectance properties of sorghum. European Journal of Agronomy, 22(4), 391-403. https://doi.org/10.1016/j.eja.2004.06.005

\section{Copyrights}

Copyright for this article is retained by the author(s), with first publication rights granted to the journal.

This is an open-access article distributed under the terms and conditions of the Creative Commons Attribution license (http://creativecommons.org/licenses/by/4.0/). 